\title{
On Earth, as it is on Mars?
}

David C. Catling

\section{The small spheres of haematite, nicknamed 'blueberries', that litter the Mars landing site of NASA's rover Opportunity might have an analogue on Earth, formed from groundwater in southern Utah.}

\begin{abstract}
n Soviet times, Russians would joke, "Is there life on Mars? No, not there either". Indeed, by the late 1970s, NASA's Viking mission had revealed a cold, dry planet, hostile to life ${ }^{1}$. Then, in the 1990s, came the confluence of two strands of science: a heated debate about possible traces of ancient life in a martian meteorite ${ }^{2}$ and, in biology, increasing evidence that microbes can thrive in extreme environments. The idea of life on Mars re-emerged. The question of where to look for signs of past or present life on Mars has been guided by the principle that all life, as we know it, requires liquid water. Consequently, when NASA launched two rovers to Mars last year, one of the rovers, named Opportunity, was targeted at Terra Meridiani, a region where orbital reconnaissance had indicated abundant crystalline haematite $\left(\mathrm{Fe}_{2} \mathrm{O}_{3}\right)$, a mineral whose precursors usually form in water ${ }^{3-6}$.

On 25 January 2004, Opportunity landed in a 22-m-diameter crater in Meridiani. There the rover's camera stared across dark basaltic sand towards an outcrop, $0.5 \mathrm{~m}$ tall and $12 \mathrm{~m}$ long, of light-toned sedimentary rock near the crater rim $^{7}$. Surprisingly, the haematite was found to be in the form of spheres, typically a few millimetres in diameter and embedded in rock outcrops like "blueberries in a muffin" (in the words of Steve Squyres, the lead rover scientist). But as
\end{abstract}
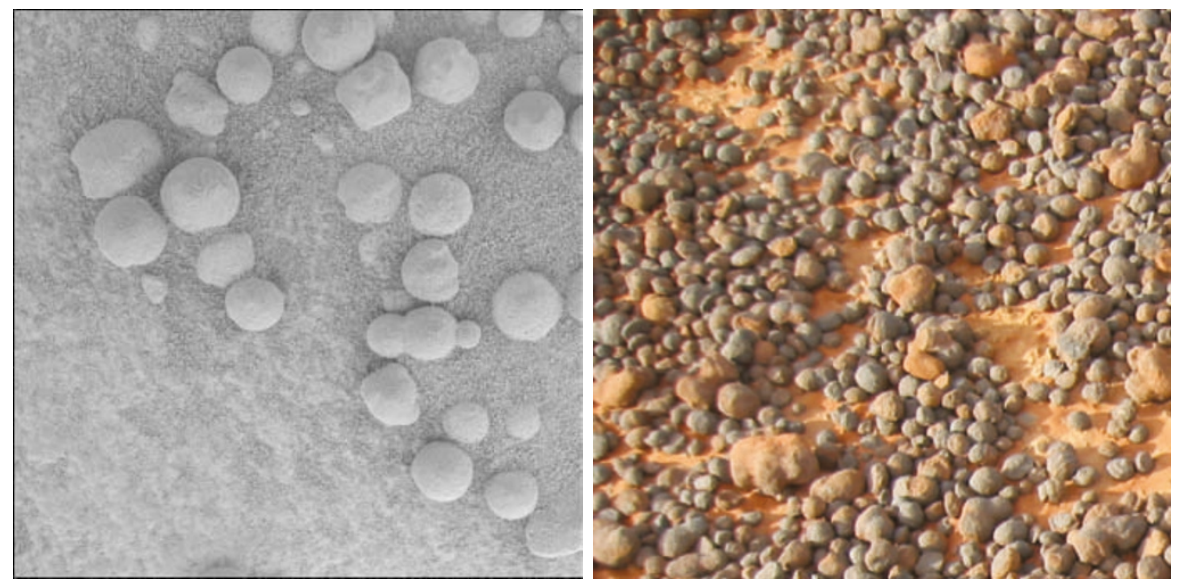

Figure 1 Earth or Mars? The NASA rover Opportunity found blueberry-size concretions of haematite on the martian surface (left), which Chan et al. ${ }^{9}$ point out are strikingly similar to these larger haematite 'marbles' found in Utah (right).

the outcrops crumble away through wind erosion, the haematite spheres, which are more resistant to erosion, are falling to the ground. Haematite spheres or their broken fragments litter the plains of Terra Meridiani and represent leftovers of a large area of rock that has vanished in the wind.

NASA's rover team has interpreted the haematite spheres as concretions, which are hard, compact mineral accumulations of different composition from their surrounding rock. Concretions form from water that carries dissolved minerals through soft sediments or porous rock: minerals precipitate around a nucleus in layers that can incorporate or replace surrounding sediment. On Earth, nucleation is sometimes attributed to microbial processes ${ }^{8}$. Concretions occur in a variety of terrestrial rocks, but is there anything like the martian blueberries?

On page 731 of this issue, Chan et al. ${ }^{9}$ report on some remarkable sandstone rocks in southern Utah that are filled with

\section{Box 1 Rock and fluid chemistry}

Craters in the haematite-rich Terra Meridiani on Mars are edged with peculiar bright rings (left image). These rings can now be interpreted as outcrops of light-toned sedimentary rock, resulting from asteroid or comet impacts that created the craters by punching into underlying light-toned rock. Over geological time, dark basaltic sand and haematite granules have filled the crater interiors, and wind has degraded the crater rims.

The light-toned outcrops contain haematite concretions and sulphates, including jarosite. Jarosite must have formed in an acidic and oxidizing environment, as indicated in a pe-pH diagram (right). Just as $\mathrm{pH}$ is defined as the logarithmic activity of aqueous hydrogen ions $\left(\mathrm{pH} \equiv-\log _{10}\left(a_{\mathrm{H}^{+}}\right)\right)$ to measure acidity or alkalinity, pe is defined analogously as the logarithmic activity of electrons $\left(\mathrm{pe} \equiv-\log _{10}\left(a_{\mathrm{e}^{-}}\right)\right)$to indicate potential electron transfer that is, oxidation or reduction. (The diagram is drawn for $25^{\circ} \mathrm{C}, \mathrm{CO}_{2}$ at a pressure of 0.01 bar, and assumed activities of dissolved iron, sulphur and potassium of $10^{-4}, 10^{-2}$ and $10^{-4}$, respectively. Activity is concentration corrected for non-ideal behaviour.)

Acidic water can transport iron as $\mathrm{Fe}^{2+}(\mathrm{aq})$, which commonly

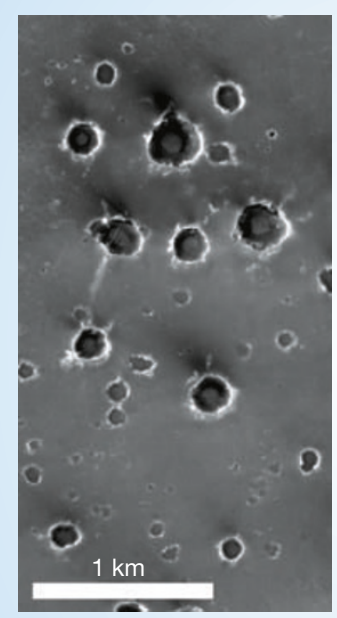

precipitates in more alkaline and oxidizing conditions as ferrihydrite, $\mathrm{Fe}(\mathrm{OH})_{3}$. Over time and with warm temperatures, ferrihydrite

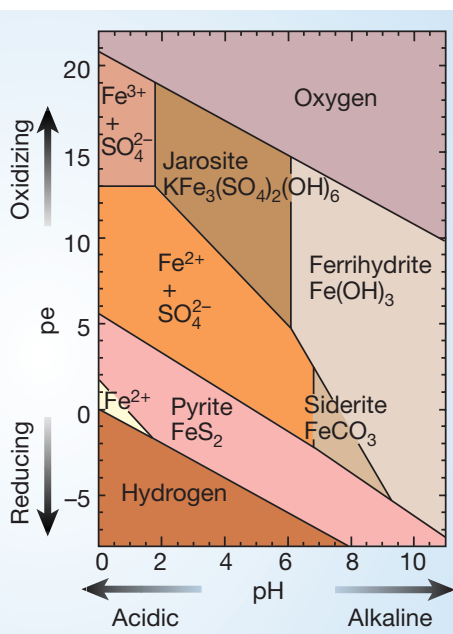

dehydrates to goethite ( $\mathrm{FeOOH}$ ) and then haematite $\left(\mathrm{Fe}_{2} \mathrm{O}_{3}\right)$, displacing the jarosite stability field in the pe-pH diagram. 
haematite concretions. As on Mars, the weathering of these rocks causes the concretions to tumble to the ground and spread across the surrounding plains. There the concretions become smooth and shiny from wind abrasion, and their diameters range from millimetres to centimetres. The loose Utah concretions roll like marbles into depressions, forming 'puddles', just like their martian counterparts (Fig. 1).

The host rock for the Utah concretions is Navajo Sandstone. This rock derives from a vast desert of sand dunes that was deposited by trade winds in the Jurassic, when Utah was situated in the tropics. Microscopic ironoxide films coat the sand grains and impart vivid red and pink colours to the sandstone. Fine iron oxides are reddish, unlike the brownish-black colour of densely cemented iron oxide in haematite concretions. Voids between Navajo Sandstone grains, which were sorted to uniform size by ancient winds, render the sandstone porous like a sponge. Fluids that are reducing, acidic, hot, or some combination of these, can mobilize iron. In certain areas, Navajo Sandstone has been bleached white by groundwater that dissolved the fine iron oxides. Where iron-rich fluids encountered more oxidizing or alkaline microenvironments, iron precipitated and cemented into concretions. But because iron is poorly soluble, large amounts of groundwater were needed - Chan et al. ${ }^{9}$ estimate $100 \mathrm{~kg}$ of water per gram of iron.

How good an analogue are the Utah concretions to those on Mars? There are important similarities, which include the surface accumulations, iron-rich fluids, porous host rock and significant volumes of fluid. But Chan et al. also note key differences. Opportunity's spectrometers and camera indicate that the martian haematite is pure, crystalline and grey. In contrast, the Utah concretions are mostly quartz, with brownish-black haematite cement as a secondary component. Consequently, the infrared spectrum that alerted us to haematite on Mars is unlikely to match a quartz-dominated spectrum from the Utah concretions.

Fine-grained Navajo Sandstone is comparable to the fine texture of the sedimentary rocks in Terra Meridiani. But the martian rocks are compositionally quite different and contain up to $40 \%$ sulphates, suggesting that they were deposited in an evaporating brine $^{7}$. NASA's rover team has reported the presence of jarosite, $\mathrm{KFe}_{3}\left(\mathrm{SO}_{4}\right)_{2}(\mathrm{OH})_{6}$, which, from thermodynamic considerations, implies an acidic environment (see Box 1). Thus, on Mars it was probably acidic water, rather than the reducing, hydrocarbon-rich fluids inferred for Utah, that mobilized iron. Acidity might have derived from dissolved carbon dioxide, given Mars's $\mathrm{CO}_{2}$-dominated atmosphere, but such a fluid would leave behind tell-tale carbonate minerals. The absence of carbonates and the conspicuous abundance of hydrous sulphates imply that the solution probably contained sulphuric acid.

The Hopi Indians have a legend that 'moqui', or spirits of their ancestors, played games of marbles with the haematite concretions in the American southwest. Although anthropologists discourage use of the word 'moqui', to be respectful to Native Americans, New Age gem collectors sell concretions as 'moqui marbles' and claim that they are endowed with metaphysical powers. New Agers are at least partly correct in their supposition that the haematite marbles can provide answers to the questions that you might ask of them. Given the similarities ${ }^{9}$ between the marbles in Utah and on Mars, additional scientific scrutiny of the Utah concretions and how they form will probably shed further light on the similar phenomenon on Mars.

Indeed, if we could bring back concretions from Mars, much could be learned. On Earth, concretions can be valuable indicators of sediment burial history, physico-chemical conditions, palaeobiology and even palaeoclimate $^{10}$. Moreover, the detailed geochemistry of the sulphate-rich martian rocks would probably prove even more revealing. So perhaps NASA's proposed sample-return mission for 2013 should shoot for Terra Meridiani, and follow the wheel tracks of Opportunity.

David C. Catling is in the Astrobiology Program and the Department of Atmospheric Sciences,

Box 351640, University of Washington, Seattle, Washington 98195, USA.

e-mail: dcatling@u.washington.edu

1. Klein, H. P. J. Geophys. Res. 103, 28463-28466 (1998).

2. McKay, D. S. et al. Science 273, $924-930$ (1996).

3. Christensen, P. R., Morris, R. V., Lane, M. D., Bandfield, J. L. \& Malin, M. C. J. Geophys. Res. 106, 23873-23885 (2001).

4. Lane, M. D., Morris, R. V., Mertzman, S. A. \& Christensen, P. R.

J. Geophys. Res. 107, doi:10.1029/2001JE001832 (2002).

5. Catling, D. C. \& Moore, J. M. Icarus 165, 277-300 (2003).

6. Baldridge, A. M. \& Calvin, W. M. J. Geophys. Res. 109,

doi:10.1029/2003JE002066 (2004).

7. Squyres, S. W. \& Athena Science Team Int. J. Astrobiol. 3 , Suppl. S1, doi:10.1017/S14735500404001648 (2004).

8. Coleman, M. L. Mar. Geol. 113, 127-140 (1993).

9. Chan, M. A., Beitler, B., Parry, W. T., Ormö, J. \& Komatsu, G. Nature 429, 731-734 (2004).

10. Sellès-Martinnez, J. Earth Sci. Rev. 41, 177-210 (1996).

\title{
Molecular biology \\ The loader of the rings
}

\author{
Michael A. Trakselis and Stephen D. Bell
}

\section{Among the numerous molecular machines involved in the process of} DNA replication are the ring-shaped sliding clamp and the clamp loader. Intriguing structural details of their interaction are now revealed.

T he double-helical structure of DNA is an icon of our time, appearing almost daily as a backdrop to news stories about medical advances and in myriad sci-fi movies. The molecule itself consists of two inter-wound strands, the backbones of which are composed of alternating phosphate and sugar groups. Extending from the backbone into the heart of the double helix are the bases - guanine, adenine, thymine and cytosine - whose order encodes the information stored by DNA. The bases on one strand must pair precisely with those on the opposite strand, adenine with thymine and guanine with cytosine ${ }^{1}$, and this provides a simple and elegant mechanism for copying this genetic material. The double helix simply unwinds and unzips, with both strands then being used as templates for the enzyme DNA polymerase, together with a large assembly of accessory factors, to make two daughter DNA molecules. Papers published on page 724 of this issue ${ }^{2}$ and in Nature Structural and Molecular Biology ${ }^{3}$ now add to our understanding of a crucial molecular contributor to this process.

Because of a chemical asymmetry in the arrangement of DNA, one daughter strand, termed the leading strand, is synthesized continuously during DNA replication. The other, the lagging strand, is made in short segments (called Okazaki fragments) that are later joined together. Central to this process is the sliding clamp, a ring-shaped, multi-subunit molecule that encircles the DNA and binds to the DNA polymerase. As the name suggests, the sliding clamp can slide along DNA, and so provides a mechanism for tethering the DNA polymerase to the template. On the leading strand this is extremely important, because the polymerase might have to continue synthesizing DNA for more than a million bases. But the clamp is also important on the lagging strand, because several of the factors involved in processing the Okazaki fragments use it as a scaffold for their assembly ${ }^{4}$.

The ring-shaped nature of the sliding clamp presents a simple topological problem: how is DNA introduced into the hole in the clamp's centre? This is the job of a complex molecular engine termed the clamp loader, which must somehow open the sliding clamp, pass DNA into the ring and then reseal it. These requirements are a common theme in several DNA-based processes. Higher organisms, for instance, also possess a DNA-repair-specific sliding clamp and clamp loader, and it is likely that similarities will be found in earlier stages in the 